\title{
Overview of the Upper Atmosphere Research Satellite: Observations from 1991 to 2002
}

\author{
Charles H. Jackman and Anne R. Douglass
}

\section{Brief, Popular Summary of the Paper:}

This paper provides a brief review of the Upper Atmosphere Research Satellite (UARS) mission. A history of the UARS program is included. The ten instruments aboard UARS and their measurements, which cover the solar and particle inputs and the winds and the chemical components of the middle and upper atmosphere, are described. The UARS operations and several anomalies are discussed with information included on the impact of these problems, some with loss of satellite capability. The primary UARS mission from launch in September 1991 through September 2001 is highlighted. The present UARS "traceability" mission (since October 2001), wherein UARS measurements are used to help validate and calibrate instruments on new satellites, is described. Current and future missions supported within this UARS "traceability" mission are listed.

The valuable science resulting from UARS measurements and data analysis by a capable investigator team is mentioned in the study through referencing three special UARS issues of journals, as well as directing the reader to the UARS website (http://umpgal.gsfc.nasa.gov) where over 800 UARS-related publications are listed. The reader is also informed about the most convenient way to access UARS data, which is through the NASA Goddard Space Flight Center Distributed Active Archive Center (http://daac.gsfc.nasa.gov). 


\title{
OVERVIEW OF THE UPPER ATMOSPHERE RESEARCH SATELLITE: OBSERVATIONS FROM 1991 TO 2002
}

\author{
Charles H. Jackman and Anne R. Douglass \\ Code 916, NASA Goddard Space Flight Center, Greenbelt, MD 20771, USA
}

\begin{abstract}
The Upper Atmosphere Research Satellite (UARS) was launched in September 1991 by the Space Shuttle Discovery and continues to make relevant atmospheric measurements (as of October 2002). This successful satellite has fostered a better understanding of the middle atmospheric processes, especially those important in the control of ozone. Seven of the original ten instruments aboard the UARS are still functional and six instruments regularly make measurements. The UARS is in a stable observing configuration, in spite of experiencing several anomalies over its lifetime. It is expected that the UARS will overlap the Earth Observing System (EOS) Aura satellite (scheduled launch in January 2004) for several months before the end of the UARS mission.
\end{abstract}

\section{INTRODUCTION}

The Upper Atmosphere Research Satellite (UARS) was launched in September 1991 aboard the Space Shuttle Discovery (STS-48). The UARS was the first satellite dedicated entirely to increasing understanding of the chemistry and dynamics of the Earth's stratosphere and mesosphere. UARS is considered the first of the Mission to Planet Earth series of National Aeronautics and Space Administrations (NASA) spacecraft. Nine instruments (SOLSTICE, SUSIM, PEM, HRDI, WINDII, HALOE, MLS, CLAES, ISAMS) were chosen through an open proposal selection process. An additional instrument, ACRIM II, was given a flight of opportunity on the UARS spacecraft. The UARS was deployed from the shuttle into a $585 \mathrm{~km}, 57$-degree inclination orbit on September 14, 1991, two days after launch.

UARS mission success was achieved eighteen months after launch in March 1993 after observing two Northern Hemisphere winters. As of October 2002, eleven years after launch, the UARS continues to operate and make relevant measurements. The UARS is in a stable observing configuration, in spite of experiencing several anomalies, which have impacted the data tape storage and power available and the pointing accuracy. Barring any major anomalies, the future plan is to operate the UARS for several months past the launch of the Earth Observing System (EOS) Aura satellite (presently scheduled for January 2004). The UARS instruments will be used to help validate and calibrate the EOS Aura instruments and allow the continuation of long-term measurements of several constituents including $\mathrm{O}_{3}, \mathrm{HCl}, \mathrm{H}_{2} \mathrm{O}, \mathrm{CH}_{4}$, and $\mathrm{NO}_{2}$.

\section{UARS INSTRUMENTS AND OPERATIONS}

\section{UARS Instruments}

UARS instruments measure parameters relevant to understanding the Earth's atmosphere. Three instruments, ACRIM II, SOLSTICE, and SUSIM, observe solar inputs. The PEM instrument measures atmospheric particle fluxes. The HRDI and WINDII instruments observe the winds in the middle and upper atmosphere (stratosphere, mesosphere, and thermosphere). Four instruments, HALOE, MLS, CLAES, and ISAMS, measure chemical constituents that are important in the middle atmosphere (stratosphere and mesosphere). Table 1 provides a brief description of these instruments and their capabilities. 
Table 1. UARS instrument information. Detailed instrument descriptions are found in the Journal of Geophysical Research (98(D6), 10643-10814, 1993).

\begin{tabular}{|c|c|c|c|}
\hline INSTRUMENT & TECHNIQUE & MEASUREMENT & $\begin{array}{l}\text { PRESENT PRINCIPAL } \\
\text { INVESTIGATOR } \\
\end{array}$ \\
\hline $\begin{array}{l}\text { ACRIM II - Active Cavity } \\
\text { Radiometer Irradiance } \\
\text { Monitor }\end{array}$ & $\begin{array}{l}\text { Full disk solar irradiance } \\
\text { radiometer }\end{array}$ & Total solar irradiance & $\begin{array}{l}\text { R. C. Willson, Columbia } \\
\text { University, U.S.A. }\end{array}$ \\
\hline $\begin{array}{l}\text { SOLSTICE - Solar/stellar } \\
\text { Irradiance Comparison } \\
\text { Experiment } \\
\end{array}$ & $\begin{array}{l}\text { Full disk solar irradiance } \\
\text { spectrometer incorporating } \\
\text { stellar comparison }\end{array}$ & $\begin{array}{l}\text { Solar ultraviolet from } 115 \\
\text { to } 430 \mathrm{~nm}\end{array}$ & $\begin{array}{l}\text { G. J. Rottman, University } \\
\text { of Colorado, U.S.A. }\end{array}$ \\
\hline $\begin{array}{l}\text { SUSIM - Solar Ultraviolet } \\
\text { Spectral Irradiance } \\
\text { Monitor }\end{array}$ & $\begin{array}{l}\text { Full disk solar irradiance } \\
\text { spectrometer incorporating } \\
\text { onboard calibration }\end{array}$ & $\begin{array}{l}\text { Solar ultraviolet from } 120 \\
\text { to } 400 \mathrm{~nm}\end{array}$ & $\begin{array}{l}\text { J. W. Cook, Naval } \\
\text { Research Laboratory, } \\
\text { U.S.A. } \\
\end{array}$ \\
\hline $\begin{array}{l}\text { PEM - Particle } \\
\text { Environment Monitor }\end{array}$ & $\begin{array}{l}\text { Electron, proton, and X- } \\
\text { ray spectrometers and a } \\
\text { magnetometer }\end{array}$ & $\begin{array}{l}\text { Energetic particle and } \mathrm{X} \text { - } \\
\text { ray flux and the magnetic } \\
\text { field }\end{array}$ & $\begin{array}{l}\text { J. D. Winningham, } \\
\text { Southwest Research } \\
\text { Institute, U.S.A. }\end{array}$ \\
\hline $\begin{array}{l}\text { HRDI - High Resolution } \\
\text { Doppler Imager }\end{array}$ & $\begin{array}{l}\text { Fabry-Perot interferometer } \\
\text { sensing atmospheric } \\
\text { emission and absorption }\end{array}$ & $\begin{array}{l}\text { Mesospheric winds, } \mathrm{O}_{3} \text {, } \\
\text { and } \mathrm{T} \text { and stratospheric } \\
\text { winds }\end{array}$ & $\begin{array}{l}\text { W. R. Skinner, University } \\
\text { of Michigan, U.S.A. }\end{array}$ \\
\hline $\begin{array}{l}\text { WINDII - Wind Imaging } \\
\text { Interferometer Sounder }\end{array}$ & $\begin{array}{l}\text { Michelson interferometer } \\
\text { sensing atmospheric } \\
\text { airglow emission } \\
\end{array}$ & $\begin{array}{l}\text { Mesospheric and } \\
\text { thermospheric winds and } \mathrm{T}\end{array}$ & $\begin{array}{l}\text { G. G. Shepherd, York } \\
\text { University, CANADA }\end{array}$ \\
\hline $\begin{array}{l}\text { HALOE - Halogen } \\
\text { Occultation Experiment }\end{array}$ & $\begin{array}{l}\text { Gas filter/radiometer } \\
\text { sensing atmospheric } \\
\text { absorption of sunlight }\end{array}$ & $\begin{array}{l}\mathrm{T}, \mathrm{O}_{3}, \mathrm{HCl}, \mathrm{HF}, \mathrm{NO}, \mathrm{NO}_{2} \\
\mathrm{CH}_{4}, \mathrm{H}_{2} \mathrm{O} \text {, Aerosols }\end{array}$ & $\begin{array}{l}\text { J. M. Russell, Hampton } \\
\text { University, U.S.A. }\end{array}$ \\
\hline $\begin{array}{l}\text { MLS - Microwave Limb } \\
\text { Sounder }\end{array}$ & Microwave radiometer & $\begin{array}{l}\mathrm{T}, \mathrm{O}_{3}, \mathrm{ClO}, \mathrm{H}_{2} \mathrm{O}, \mathrm{SO}_{2} \\
\mathrm{HNO}_{3}\end{array}$ & $\begin{array}{l}\text { J. W. Waters, Jet } \\
\text { Propulsion Laboratory, } \\
\text { U.S.A. }\end{array}$ \\
\hline $\begin{array}{l}\text { CLAES - Cryogenic Limb } \\
\text { Array Etalon Spectrometer }\end{array}$ & $\begin{array}{l}\text { Solid-cryogen cooled } \\
\text { interferometer sensing } \\
\text { atmospheric infrared } \\
\text { emissions }\end{array}$ & $\begin{array}{l}\mathrm{T}, \mathrm{O}_{3}, \mathrm{ClONO}_{2}, \mathrm{~N}_{2} \mathrm{O}, \mathrm{CH}_{4}, \\
\mathrm{HNO}_{3}, \mathrm{~N}_{2} \mathrm{O}_{5}, \mathrm{CF}_{2} \mathrm{Cl}_{2}, \\
\mathrm{CFCl}_{3}, \mathrm{NO}, \mathrm{NO}_{2}, \mathrm{HCl}, \\
\text { Aerosols }\end{array}$ & $\begin{array}{l}\text { A. E. Roche, Lockheed } \\
\text { Martin Palo Alto Research } \\
\text { Laboratory, U.S.A. }\end{array}$ \\
\hline $\begin{array}{l}\text { ISAMS - Improved } \\
\text { Stratospheric and } \\
\text { Mesospheric Sounder }\end{array}$ & $\begin{array}{l}\text { Mechanically cooled } \\
\text { radiometer sensing } \\
\text { atmospheric infrared } \\
\text { emissions }\end{array}$ & $\begin{array}{l}\mathrm{T}, \mathrm{O}_{3}, \mathrm{CO}, \mathrm{HNO}_{3}, \mathrm{NO}, \\
\mathrm{NO}_{2}, \mathrm{~N}_{2} \mathrm{O}, \mathrm{CO}, \mathrm{H}_{2} \mathrm{O} \\
\mathrm{N}_{2} \mathrm{O}_{5}, \mathrm{HNO}_{3}, \text { Aerosols }\end{array}$ & $\begin{array}{l}\text { F. W. Taylor, Oxford } \\
\text { University, UNITED } \\
\text { KINGDOM }\end{array}$ \\
\hline
\end{tabular}

All the instruments have provided invaluable measurements about the external forcing, transport, and chemistry of the Earth's middle atmosphere, especially in regards to the control of ozone. All of the chemical constituent teams were able to develop algorithms to derive additional constituents. For example, since the UARS was launched shortly after the eruption of Mt. Pinatubo in June 1991, the atmosphere was still contaminated with high levels of sulfate aerosol and three of the instrument teams (HALOE, CLAES, and ISAMS) modified their algorithms to detect aerosols. The MLS instrument was unaffected by the aerosol level.

The UARS was conceived in the early 1980's when it was thought that the humankind influence on ozone would be most apparent in the upper stratosphere. In the late 1980's after the discovery of the Antarctic ozone hole, it became apparent that the humankind influence was most important in the lower stratosphere. The chemical constituent instrument teams were able to concentrate their efforts on improving their algorithms in this part of the atmosphere and many breakthroughs were accomplished. For example, both the HALOE and MLS instrument teams are now able to derive $\mathrm{H}_{2} \mathrm{O}$ in the upper troposphere.

After functioning from turn on October 28,1991 the ISAMS chopper wheel ceased to rotate in mid-January, 1991. Attempts to restart the wheel were unsuccessful until it suddenly began to rotate again two months later. The 
mechanism failed again in July 1992 and the ISAMS ceased operations. In April 1993, the CLAES cryogen expired on schedule and the instrument ceased taking data. The MLS $183 \mathrm{GHz}$ radiometer failed about the same time. This channel measured stratospheric water vapor and mesospheric ozone. The 63 and $205 \mathrm{GHz}$ radiometers are operational and measure $\mathrm{T}, \mathrm{ClO}$, stratospheric ozone and lower stratospheric $\mathrm{HNO}_{3}$. The MLS scanning mechanism has become less reliable after many years of use and now the MLS instrument is in the standby mode. The PEM instrument has experienced failures (October 1991 and May 1999) and degradations (June 1994 and November 1998 ) in all of its low-energy proton sensors ( $<35 \mathrm{keV})$; however, its proton sensors detecting energies greater than $35 \mathrm{keV}$ remain operational as well as its electron and X-ray channels. The ACRIM II instrument started experiencing problems in May 2001 and ceased operations in November 2001.

Six (SOLSTICE, SUSIM, PEM, HRDI, WINDII, HALOE) of the original ten instruments aboard the UARS regularly take measurements.

\section{UARS Operations}

The UARS has been fortunate to have a skilled Flight Operations Team (FOT) as there have been a number of anomalies in its long lifetime. The UARS FOT was able to work around several very serious problems and changed operational procedures to continue the mission in a somewhat different mode. The UARS was also equipped with several redundancies onboard that aided in these operational changes. Three of the more serious anomalies related to data tape storage and power availability and pointing accuracy are given below.

The UARS started with two tape recorders to record observations, which would then be relayed to the ground during contacts. One tape recorder was lost early in the mission and an anomaly in October 1999 reduced the use of the remaining tape recorder to $25 \%$ of its original capacity. "Real-time" operations are needed to record much of the UARS data during two contacts of the Tracking and Data Relay Satellites in each orbit.

The rotation of the solar array led to problems from nearly the start of the mission. After several solar array related anomalies, a decision was made in May 1995 to halt the rotation of the solar array and operate the instruments on a reduced power plan. UARS experienced a further reduction in power in June 1997 with the loss of one of three batteries. A "power sharing" mode is used for the instruments with schedules determined a few weeks before the instrument operations.

The UARS relied on two star trackers for pointing accuracy during most of its mission. One star tracker failed in 1997 and the second in 2000. Since the failure of the second star tracker a methodology to point using information from the two three-axis magnetometers and the fine sun sensor was developed. These adaptations were possible due to the capabilities of the FOT and supplemental equipment onboard the satellite.

\section{UARS PRIMARY AND TRACEABILITY MISSIONS}

The UARS primary mission occurred over a ten-year period from September 1991 through September 2001. During the UARS primary mission, the focus was on the natural and anthropogenic perturbations that influenced ozone and the physical processes acting within and upon the stratosphere, mesosphere, and lower thermosphere. As of October 1, 2001, the UARS program started a new phase of its life called a "Traceability Mission." The UARS measurements are now being used primarily for the validation and calibration of measurements from recently launched satellites.

New satellites that have been launched within the UARS "Traceability Mission" time period include the NASA Thermosphere Ionosphere Meosphere Energetics and Dynamics (TIMED) satellite (launched December 2001), the NASA Stratospheric Aerosol and Gas Experiment-III (SAGE-III) satellite (launched December 2001), the European Space Agency (ESA) Environmental Satellite-1 (ENVISAT-1) satellite (launched March 2002), and the EOS Aqua satellite (launched May 2002). The schedule for UARS instrument operations has been optimized since January 2002 to aid in the validation and calibration of instruments aboard these new satellites.

Future satellites that will be launched within the UARS "Traceability Mission" include the NASA Solar Radiation and Climate Experiment (SORCE) satellite scheduled to be launched in December 2002, the Japanese Advanced Earth Observing Satellite-II (ADEOS-II) satellite scheduled to be launched in late 2002, the Canadian Space Agency (CSA) Science Satellite-1 (SCISAT-1) satellite scheduled to be launched in early 2003, and the EOS Aura satellite scheduled to be launched in January 2004. 


\section{UARS DATA}

The UARS data were processed from instrument activations in September and October 1991 through September 2001 at the UARS Central Data Handling Facility (CDHF) located at NASA Goddard Space Flight Center (GSFC). Since October 2001 the UARS data have been processed at the individual instrument team locations. The Level 3 science data (Level 2 for HALOE) are publicly available at the GSFC Distributed Active Archive Center (DAAC). These UARS data may be accessed through the GSFC DAAC website (http://daac. gsfc. nasa.gov).

\section{UARS SCIENCE}

The UARS original science team included theoretical investigator teams as well as the ten instrument teams. These original UARS team members were complemented with the addition of Guest Investigators in 1994. Science Investigators competed for UARS science funds in 1997 and again in 2000. Special issues of the Journal of Geophysical Research (98(D6), 10643-10814, 1993; 101(D6), 9539-10473, 1996), the Geophysical Research Letters (20(12), 1215-1330, 1993), and the Journal of Atmospheric Science (51(20), 2781-3105, 1994) provide a small subset of papers relevant to the UARS mission. The UARS website (http://umpgal.gsfc.nasa.gov) provides references for over 800 UARS-related publications. Information from the UARS brochure and video are also given at this website.

The UARS measurements and subsequent data analysis has fostered many understanding breakthroughs on the middle atmospheric region. Schoeberl et al. (1994) describe several of the major scientific results in the first $2 \frac{1 / 2}{2}$ years of the UARS mission. Dessler et al. (1998) present some selected scientific highlights from the first 5 years of the UARS mission. The longevity of the UARS has allowed the determination of long-term trends and variations in constituents, winds, and external forcings. The UARS mission has been and continues to be an outstanding success. The achievements during the UARS mission were only possible due to the hard work and creativity of the hundreds of people involved with the mission over many years.

\section{ACKNOWLEDGMENTS}

The authors gratefully acknowledge the several hundred investigators, engineers, and computer specialists working on the UARS in various capacities. These people helped lead to the outstanding success of the UARS mission.

\section{REFERENCES}

Dessler, A. E., M. D. Burrage, J.-U. Grooss, J. R. Holton, J. L. Lean, S. T. Massie, M. R. Schoeberl, A. R. Douglass, and C. H. Jackman, Selected science highlights from the first 5 years of the Upper Atmosphere Research Satellite (UARS) program, Rev. Geophys., 36, 183-210, 1998.

Schoeberl, M. R., A. R. Douglass, and C. H. Jackman, Overview and highlights of the UARS mission, SPIE-The International Society for Optical Engineering, 2266, 254-265, 1994.

E-mail address of C.H. Jackman jackman@assess.gsfc.nasa.gov

Manuscript received ; revised, accepted 